\title{
molecules
}

ISSN 1420-3049

www.mdpi.com/journal/molecules

Article

\section{Neonaucline, a New Indole Alkaloid from the Leaves of Ochreinauclea maingayii (Hook. f.) Ridsd. (Rubiaceae)}

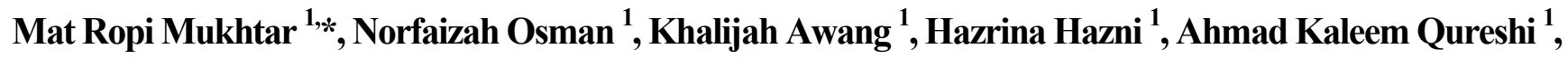
A. Hamid A. Hadi ${ }^{1}$, Kazuma Zaima ${ }^{2}$, Hiroshi Morita ${ }^{2}$ and Marc Litaudon ${ }^{3}$

1 Department of Chemistry, Faculty of Science, University of Malaya, 50603 Kuala Lumpur, Malaysia; E-Mails: faizah05@gmail.com (N.O.); khalijah@um.edu.my (K.A.); hazrinahazni@um.edu.my (H.H.); ahamid@um.edu.my (A.H.A.H.)

2 Faculty of Pharmaceutical Sciences, Hoshi University, Shinagawa-ku, Tokyo 142-8501, Japan; E-Mail: moritah@hoshi.ac.jp (H.M.)

3 Institut de Chimie de la Substances Naturelles, Centre Nationale de la Recherches Scientifique, 91198, Gif-sur Yvette, Cedex, France; E-Mail: marc.litaudon@icsn.cnrs-gif.fr (M.L.)

* Author to whom correspondence should be addressed; E-Mail: matropi@um.edu.my; Tel.: +603-7967-4048; Fax: +603-7967-4193.

Received: 25 October 2011; in revised form: 19 December 2011 / Accepted: 26 December 2011 / Published: 28 December 2011

Abstract: A new indole alkaloid; neonaucline (1), along with six known compoundsCadamine (2), naucledine (3), harmane, benzamide, cinnamide and blumenol A-were isolated from the leaves of Ochreinauclea maingayii (Rubiaceae). In addition to that of compound 1, ${ }^{13} \mathrm{C}-\mathrm{NMR}$ data of cadamine (2) and naucledine (3) were also reported. Structural elucidations of these alkaloids were performed using spectroscopic methods especially 1D- and 2D-NMR, IR, UV and LCMS-IT-TOF. The excellent vasorelaxant activity on isolated rat aorta was observed for the alkaloids $\mathbf{1}-\mathbf{3}$ after injection of each sample at $1 \times 10^{-5} \mathrm{M}$.

Keywords: Ochreinauclea maingayii; neonaucline; nauledine; cadamine; Rubiaceae; alkaloid 


\section{Introduction}

Ochreinauclea maingayii (Hook. f.) Ridsd. (Rubiaceae) is a medium size tree distributed in Peninsular Malaysia, Borneo, Sumatra and Thailand [1-4]. The timber of Ochreinauclea species shares the standard Malaysian name "bangkal" or "mengkal" with Nauclea and Neonauclea species [5]. There has been no report of other phytochemical study and medicinal value of Ochreinauclea maingayii so far. In continuation of our research on plants from the Rubiaceae family [6], we have embarked a study on the $\mathrm{CH}_{2} \mathrm{Cl}_{2}$ extract of the plant Ochreinauclea maingayii. The present study has led to the isolation of a new indole alkaloid, neonaucline (1) together with cadamine (2) [7-9], naucledine (3) [10-13], harmane [14-15], blumenol A [16], bezamide, and cinnamide.

Figure 1. Structures of neonaucline (1), cadamine (2), and naucledine (3).

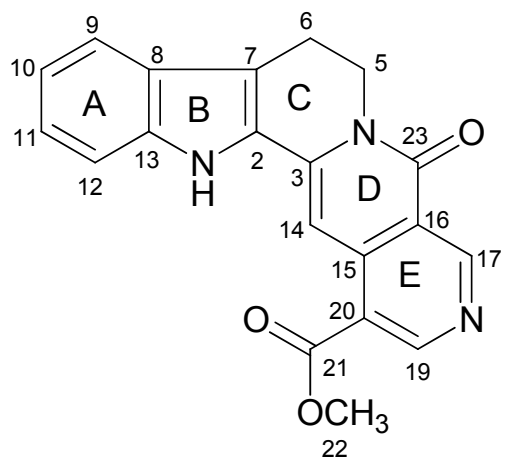

(1)

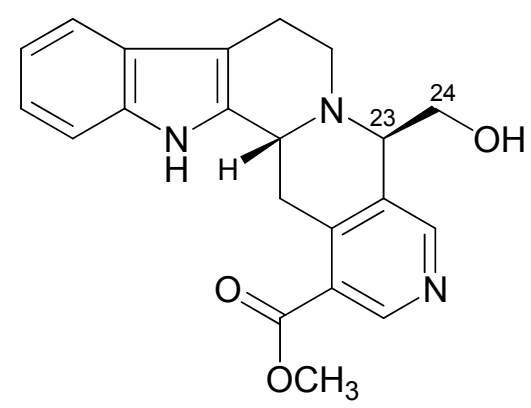

(2)

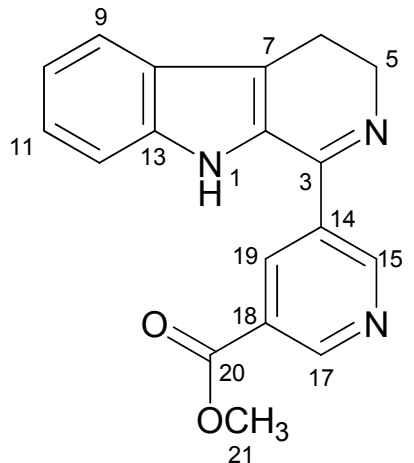

(3)

\section{Results and Discussion}

Neonaucline (1) was isolated as a yellowish amorphous solid. The LCMS-IT-TOF spectrum of $\mathbf{1}$ showed a pseudomolecular ion peak, $[\mathrm{M}+\mathrm{H}]$ at $\mathrm{m} / \mathrm{z} 346.1140$, corresponding to the molecular formula of $\mathrm{C}_{20} \mathrm{H}_{16} \mathrm{~N}_{3} \mathrm{O}_{3}$. The IR spectrum revealed absorption bands at 3,364 and $1,731 \mathrm{~cm}^{-1}$ for the stretching vibrations of $-\mathrm{NH}$ and $-\mathrm{CO}$ groups respectively. In the ${ }^{1} \mathrm{H}-\mathrm{NMR}$ spectrum, signals for seven aromatic protons due to one methoxy singlet and one $-\mathrm{CH}_{2}-\mathrm{CH}_{2}-\mathrm{N}-$ group were observed, thus suggesting an indolopyridinequinolizinone type of skeleton [17]. Among the seven aromatic proton signals, two resonated as doublet of doublets (dd) at $\delta 7.35$ and 7.18 (H-10 and H11), two doublets at $\delta 7.64$ and 7.46 (H-9 and H-12), and three singlets at $\delta 7.88,9.32$ and 9.69 assignable to H-14, H-17, and H-19, respectively. Further analysis of the ${ }^{1} \mathrm{H}-\mathrm{NMR}$ and ${ }^{13} \mathrm{C}-\mathrm{NMR}$ spectra showed that $\mathbf{1}$ is very similar to naucletine [18] except that the former revealed the presence of a singlet representing a methoxy group at $\delta_{\mathrm{H}} 4.00$ and $\delta_{\mathrm{C}} 52.5$. The position of COOMe attached to C-20 $(\delta 120.4)$ in ring E was confirmed based on the HMBC correlations of H-14/C-20 ( $\delta$ 120.4), H-19/C-21 ( $\delta$ 166.4), H-22/C-21 and $\mathrm{H}-17 / \mathrm{C}-23(\delta 166.4)$, respectively as shown in Figure 2 . The ${ }^{13} \mathrm{C}-\mathrm{NMR}$ spectrum revealed 20 carbon signals due to eight quaternary carbons, seven methines, two methylenes, one methoxy group and two carbonyl groups. The ${ }^{1} \mathrm{H}-\mathrm{NMR}(400 \mathrm{MHz})$ and ${ }^{13} \mathrm{C}-\mathrm{NMR}(100 \mathrm{MHz})$ spectral assignments performed by extensive 2D-NMR experiments (COSY, HSQC and HMBC) were summarized in Figure 2 and Table 1. 
Table 1. ${ }^{1} \mathrm{H}-\mathrm{NMR}(400 \mathrm{~Hz})$ and ${ }^{13} \mathrm{C}-\mathrm{NMR}(100 \mathrm{~Hz})$ spectral data of neonaucline (1) and cadamine (2) in $\mathrm{CDCl}_{3}$.

\begin{tabular}{lllll}
\hline Position & ${ }^{\mathbf{1}} \mathbf{H}\left(\boldsymbol{\delta}_{\mathbf{H}}, \mathbf{H z}\right) \mathbf{( 1 )}$ & ${ }^{\mathbf{1 3}} \mathbf{C}\left(\boldsymbol{\delta}_{\mathbf{C}}, \mathbf{C D C l}_{\mathbf{3}}\right)$ & ${ }^{\mathbf{1}} \mathbf{H}\left(\boldsymbol{\delta}_{\mathbf{H}}, \mathbf{H z}\right)(\mathbf{2})$ & ${ }^{\mathbf{1 3}} \mathbf{C}\left(\boldsymbol{\delta}_{\mathbf{C}}, \mathbf{C D C l}_{\mathbf{3}}\right)$ \\
\hline $\mathrm{N}-\mathrm{H}$ & $8.72 \mathrm{~s}$ & - & $7.95 \mathrm{~s}$ & - \\
2 & - & 127.4 & - & 134.9 \\
3 & - & 138.2 & $4.43 \mathrm{~m}$ & 46.3 \\
5 & $4.54 \mathrm{t}(2 \mathrm{H}, 6.8)$ & 40.7 & $2.94,3.22 \mathrm{~m}$ & 47.6 \\
6 & $3.19 \mathrm{t}(2 \mathrm{H}, 6.8)$ & 19.4 & $2.80,2.98 \mathrm{~m}$ & 21.9 \\
7 & - & 116.9 & - & 107.9 \\
8 & - & 125.7 & - & 126.9 \\
9 & $7.64 \mathrm{~d}(7.8)$ & 119.9 & $7.48 \mathrm{~d}(8.0)$ & 118.3 \\
10 & $7.18 \mathrm{dd}(7.8,7.8)$ & 120.9 & $7.10 \mathrm{dd}(8.0,8.0)$ & 119.4 \\
11 & $7.35 \mathrm{dd}(7.8,7.8)$ & 125.6 & $7.16 \mathrm{dd}(8.0,8.0)$ & 121.9 \\
12 & $7.46 \mathrm{~d}(7.8)$ & 111.9 & $7.27 \mathrm{~d}(8.0)$ & 111.1 \\
13 & - & 138.6 & - & 136.2 \\
14 & $7.88 \mathrm{~s}$ & 95.1 & $3.25,3.51 \mathrm{~m}$ & 28.3 \\
15 & - & 141.9 & - & 124.5 \\
16 & - & 117.8 & - & 130.8 \\
17 & $9.32 \mathrm{~s}$ & 155.4 & $8.51 \mathrm{~s}$ & 151.8 \\
19 & $9.69 \mathrm{~s}$ & 154.2 & $8.96 \mathrm{~s}$ & 150.0 \\
20 & & 120.4 & - & 144.8 \\
21 & - & 166.4 & - & 166.3 \\
$22-\mathrm{OMe}$ & $4.00 \mathrm{~s}$ & 52.5 & $3.88 \mathrm{~s}$ & 52.4 \\
23 & - & 166.4 & $4.10 \mathrm{~m}$ & 62.6 \\
24 & - & - & $3.61,3.75 \mathrm{~m}$ & 63.6 \\
\hline
\end{tabular}

Figure 2. Selected 2D NMR correlations of neonaucline (1).

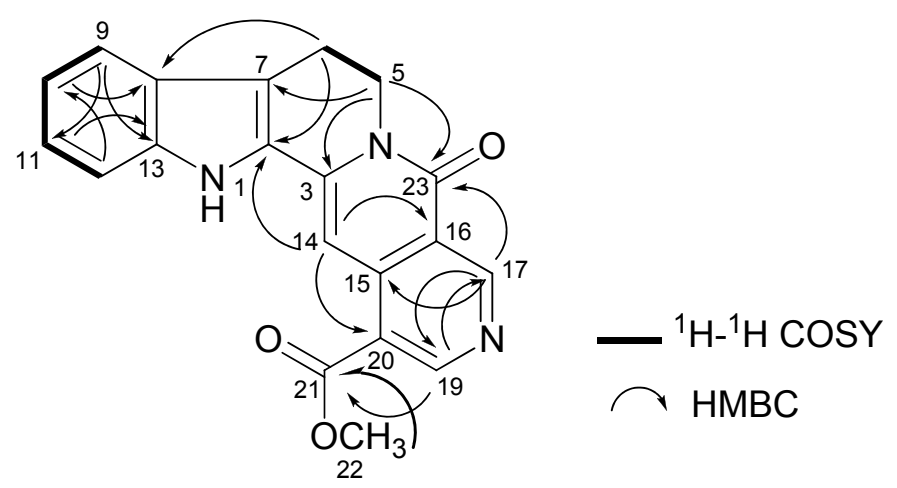

Cadamine (2) and naucledine (3) were isolated as a reddish and yellowish amorphous solid. The LCMS-IT-TOFF spectra showed pseudomolecular ion peaks, $[\mathrm{M}+\mathrm{H}]^{+}$at $m / z 364.1638\left[\mathrm{C}_{21} \mathrm{H}_{21} \mathrm{~N}_{3} \mathrm{O}_{3}\right]$ and $m / z$ 306.1213 $\left[\mathrm{C}_{18} \mathrm{H}_{15} \mathrm{~N}_{3} \mathrm{O}_{3}\right]$, respectively. The ${ }^{1} \mathrm{H}-\mathrm{NMR}$ data of cadamine (2) was reported previously based on cadamine acetate [7] whereas 3 were first isolated from Nauclea diderrichi [10]. We herein report the ${ }^{13} \mathrm{C}-\mathrm{NMR}$ data for both compounds which has not been reported yet [7-13]. In view of that, complete assignments were established through various NMR measurements; DEPT, HMQC, HMBC and NOESY spectra. The ${ }^{13} \mathrm{C}-\mathrm{NMR}$ spectra of cadamine (2) and naucledine (3) indicated the presence of 21 and 18 carbons, respectively, as shown in Tables 1 and 2. 
Table 2. ${ }^{1} \mathrm{H}-\mathrm{NMR}$ (in DMSO-d6 and $\left.\mathrm{CDCl}_{3}\right)$ and ${ }^{13} \mathrm{C}-\mathrm{NMR}\left(100 \mathrm{~Hz}, \mathrm{CDCl}_{3}\right)$ spectral data of naucledine (3).

\begin{tabular}{|c|c|c|c|}
\hline Position & ${ }^{* 1} \mathrm{H}\left(\tau\right.$, DMSO- $\left.d_{6}\right)$ & ${ }^{1} \mathrm{H}\left(\delta_{\mathrm{H}}, \mathrm{Hz}\right)$ & ${ }^{13} \mathrm{C}\left(\delta_{\mathrm{C}}\right)$ \\
\hline $\mathrm{N}-\mathrm{H}$ & $0.90 \mathrm{~s}$ & $8.35 \mathrm{~s}$ & \\
\hline 2 & - & - & 126.3 \\
\hline 3 & - & - & 156.3 \\
\hline 5 & $6.36 \mathrm{~m}$ & $4.13(\mathrm{t}, 6.8)$ & 49.3 \\
\hline 6 & $6.96 \mathrm{~m}$ & $3.03(\mathrm{t}, 6.8)$ & 19.3 \\
\hline 7 & - & - & \\
\hline 8 & - & - & 125.5 \\
\hline 9 & & $7.68(\mathrm{~d}, 8.3)$ & 120.3 \\
\hline 10 & $2.2-3.1$ & $7.23(\mathrm{dd}, 7.8,8.3)$ & 120.9 \\
\hline 11$\}$ & (3peaks) & $7.33(\mathrm{dd}, 7.8,8.3)$ & 125.4 \\
\hline 12 & & $7.42(\mathrm{~d}, 8.3)$ & 112.4 \\
\hline 13 & - & - & 136.9 \\
\hline 14 & - & - & 125.5 \\
\hline 15 & $0.65 d$ & $9.30(\mathrm{~d}, 1.96)$ & 151.8 \\
\hline 17 & $0.73 d$ & $9.18(\mathrm{~d}, 1.96)$ & 152.6 \\
\hline 18 & - & - & 133.3 \\
\hline 19 & $0.88 \mathrm{t}$ & $8.68(\mathrm{t}, 2.20,1.96)$ & 136.5 \\
\hline 20 & & & 165.5 \\
\hline 21 & $6.08 \mathrm{~s}(3 \mathrm{H})$ & $3.98(\mathrm{~s})$ & 52.8 \\
\hline
\end{tabular}

Vasodilators are useful for treatment of cerebral vasospasm and hypertension, and for improvement of peripheral circulation [19]. When phenylephrine (PE) $3 \times 10^{-7} \mathrm{M}$ was applied to thoracic aortic rings with endothelium after achieving a maximal response, we added neonaucline $\left(1 ; 1 \times 10^{-5} \mathrm{M}\right)$, cadamine $\left(2 ; 1 \times 10^{-5} \mathrm{M}\right)$, and naucledine $\left(3 ; 1 \times 10^{-5} \mathrm{M}\right)$. The excellent activity could be observed for these three alkaloids (1-3) after injection of each sample at $1 \times 10^{-5} \mathrm{M}$ as shown in Figure 3 .

Figure 3. Vasorelaxant effects of neonaucline $\left(1 ; 10^{-5} \mathrm{M}\right)$, cadamine $\left(2 ; 10^{-5} \mathrm{M}\right)$, and naucledine $\left(3 ; 10^{-5} \mathrm{M}\right)$ on endothelium-intact rings cut from rat arteries pre-contracted with PE $(0.3 \mu \mathrm{M})$.

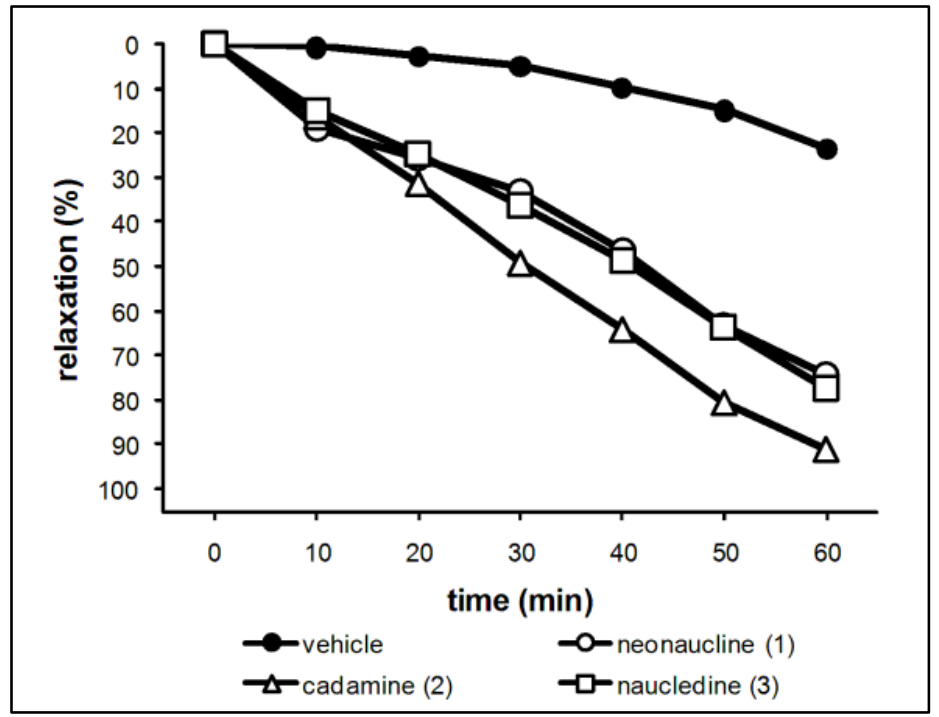


In the previous papers, we have reported vasorelaxant activities of some bisbenzylisoquinoline alkaloids such as $\alpha^{\prime}$-oxoperakensimines A-C from Alseodaphne perakensis and A. corneri [20,21], and $\mathrm{N}$-allyllaurolitsine from Litsea lancifolia [22]. These vasorelaxant effects may be mediated through the increased release of NO from endothelial cells, inhibition of calcium influx from extracellular space through voltage-dependent calcium channels (VDC) and/or receptor-operated $\mathrm{Ca}^{2+}$-channels (ROC), and also through the increased release of NO from endotheliul cells and opening of voltage-gated $\mathrm{K}^{+}$-channels. The mode of action of these alkaloids on vasorelaxant activity is under investigation.

\section{Experimental}

\section{General}

Spectra were recorded on the following instruments: UV, Shimadzu UV-160A UV-Visible spectrophotometer; IR, Perkin Elmer 1600; NMR, JEOL ECA 400 MHz; LCMS-IT-TOF, Shimadzu. All solvents, except those used for bulk extraction are AR grade. Silica gel $60 \mathrm{~F}_{254}$ was used for column chromatography. Glass and aluminium supported silica gel $60 \mathrm{~F}_{254}$ plates were used for preparative TLC. TLC sports were visualized under UV light (254 and $365 \mathrm{~nm}$ ) followed by spraying with Dragendorff's reagent for alkaloid detection.

Plant Material: The leaves of Ochreinauclea maingayii were collected at Reserve Forest Sg. Tekam, Jerantut, Pahang, Malaysia, in 17 February 2009. The plant species was identified by Prof. Colin E. Ridsdale from Leiden University, Netherland. A voucher specimen (KL5625) was deposited in the Herbarium of Department of Chemistry, University of Malaya, Malaysia.

Extraction and the isolation: A total of $2.0 \mathrm{~kg}$ of dried and grounded leaves of Ochreinauclea maingayii was extracted with $\mathrm{CH}_{2} \mathrm{Cl}_{2}$. Extraction of alkaloids was carried out in the usual manner, which has been described in detail [17-19]. Finally, the extract was concentrated to give crude alkaloids of $3.0 \mathrm{~g}$ in weight. The isolation and purification of compounds $\mathbf{1}-\mathbf{3}$ by a small column chromatography (column dimension $=1.0 \mathrm{~cm}$, length $=25 \mathrm{~cm}$, silica gel 60, 70-230 mesh ASTM; Merck 7734) and preparative TLC (PTLC Merck KGaA silica gel $60 \mathrm{~F}_{254}$ ) yielded $0.13 \%$ of neonaucline (1), $\left(\mathrm{CH}_{2} \mathrm{Cl}_{2}-\mathrm{MeOH}\right.$; 98:2), cadamine (2), (0.76\%, $\left.\mathrm{CH}_{2} \mathrm{Cl}_{2}-\mathrm{MeOH} ; 96: 4\right)$ and naucledine (3), (0.08\%, $\left.\mathrm{CH}_{2} \mathrm{Cl}_{2}-\mathrm{MeOH} ; 96: 4\right)$, respectively.

Vasodilation Assay: The vasorelaxant activities of all the alkaloids 1-3 were tested using the same procedure as reported previously by Morita et al. [20]. The animal experimental studies were conducted in accordance with the Guiding Principles for the Care and Use of Laboratory Animals, Hoshi University and under the supervision of the Committee on Animal Research of Hoshi University, which is accredited by the Ministry of Education, Science, Sports Culture, and Technology of Japan.

Neonaucline (1). Yellowish amorphous solid, LCMS-IT-TOFF at $\mathrm{m} / z 346.1140\left([\mathrm{M}+\mathrm{H}]^{+}\right.$; calcd for $\left.\mathrm{C}_{20} \mathrm{H}_{16} \mathrm{~N}_{3} \mathrm{O}_{3}, 346.1192\right)$; UV (MeOH) 376, 284, 204nm; IR (KBr) $\lambda_{\max } 3,364,1,737$ and $1,731 \mathrm{~cm}^{-1}$; ${ }^{1} \mathrm{H}$ and ${ }^{13} \mathrm{C}$-NMR: see Table 1. 


\section{Conclusions}

This is the first report on the phytochemical and biological studies on the species of Ochreinauclea maingayii. One new indole alkaloid- neonaucline (1) along with six known compounds- three alkaloids (cadamine 2, naucledine 3 and harmane), one nor-isoprenoid-type (blumenol A), bezamide and cinnamide were isolated from the leaves of this species. The proposed biogenesis of $\mathbf{1}$ from cadamine (2) is illustrated in Scheme 1. The latter is oxidized at C-24 followed by decarboxilation and protonation of the carbanion to give compound 4 . Then, 4 will be hydroxylated at C-23 followed by oxidation to give neonaucline (1). The excellent vasorelaxant activity on isolated rat aorta was observed for the alkaloids 1-3 after injection of each sample at $1 \times 10^{-5} \mathrm{M}$.

Scheme 1. Biogenetic pathway for neonaucline (1).<smiles>[Z4]C1c2cncc(C(=O)OC)c2C[C@H]2c3[nH]c4ccccc4c3CCN12</smiles>

Cadamine (2)

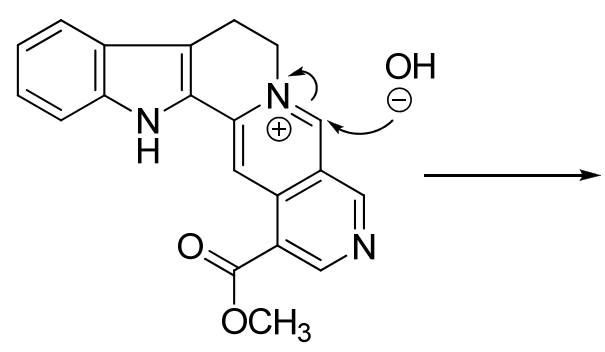<smiles>COC(=O)c1cncc2c1C[C@H]1c3[nH]c4ccccc4c3CCN1CC2C(=O)O</smiles><smiles>COC(=O)c1cncc2c1C=C1c3[nH]c4ccccc4c3CCN1C2O</smiles>

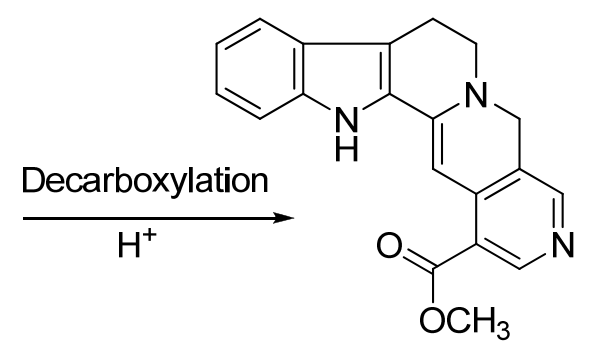

(4)

\section{Acknowledgments}

This work was supported by the FRGS (FP016/2010A) and Postgraduate Research Grants (PS344/2010A), University of Malaya, Malaysia and CNRS, France. This work was carried out within the framework of an official agreement between the CNRS and the University of Malaya (Malaysia). The authors also want to thank Prof. C.E. Ridsdale from Leiden University, The Netherlands for the identification of the plant KL5625.

\section{Conflict of Interest}

The authors declare no conflict of interest. 


\section{References and Notes}

1. Ridsdale, C.E. A revision of the tribe Naucleeae s.s. (Rubiaceae). Blumea 1978, 24, 307-366.

2. Razafimandimbson, S.G.; Bremer, B. Phylogeny and classification of Naucleeae S.L.(Rubiaceae) Inferred from molecular (ITS, ${ }_{R} B C L$, and $\left.{ }_{T} R N T-F\right)$ and morphological data. Am. J. Bot. 2002, 89, 1027-1041.

3. Chandrika, M.; Rai, R.V. An assessment of genetic stability in micropropagated plants of Ochreinauclea missionis by RAPD markers. Cur. Trd. Biotech. Pharm. 2009, 3, 320-328.

4. Chandrika, M.; Rai, R.V. Genetic fidelity in micropropagated plantlets of Ochreinauclea missionis and endemic, threatened and medicinal tree using ISSR markers. Afr. J. Biotechnol. 2009, 8, 2933-2938.

5. Lim, S.C.; Gan, K.S.; Choo, K.T. Identification and utilization of lesser-known commercial timbers in Peninsular Malaysia 1: Ara, Bangkal, Bebusok and Bekoi. Timber Tech. Bull. 2004, 29, 3-5.

6. Qureshi, A.K.; Mukhtar, M.R.; Hirasawa, Y.; Hosoya, T.; Nugroho; Morita, H.; Shirota, O.; Mohamad, K.; Hadi, A.H.A.; Litaudon, M.; Awang, K. Neolamarckines A and B, new indole alkaloids from Neolamarckia cadamba. Chem. Pharm. Bull. 2011, 59, 291-293.

7. Brown, R.T.; Chapple, C.L. Anthocephalus alkaloids: Cadamine and isocadamine. Tetrahedron Lett. 1976, 19, 1629-1630.

8. Zhou, H.; He, N.C.; Wang, T.J.; Hao, X.J. Indole alkaloids from the leaves of Antocephalus chinesis. Helv. Chim. Acta 2008, 91, 2148-2152.

9. Ohba, M.; Kubo, H.; Ishibashi, H. A chiral synthesis of the Strychos and Ophiorrhiza alkaloid normalidine. Tetrahedron 2000, 56, 7751-7761.

10. McLean, S.; Murray, D.G. Isolation of indole ( $\beta$-carboline), pyridine, and indole-pyridine alkaloids from Nauclea diderrichii. Can. J. Chem. 1970, 48, 867-868.

11. Murray, D.G.; Szakolcai, A.; Mclean, S. The constituents of Nauclea diderrichii. Part III. Indolepyridine alkaloids. Can. J. Chem. 1972, 50, 1486-1495.

12. McLean, S.; Murray, D.G. The constituents of Nauclea diderrichii. Part IV. Miscellaneous substance; Biogenetic considerations. Can. J. Chem. 1972, 50, 1496-1501.

13. McLean, S.; Dmitrienko, G.I.; Szakolcai, A. Constituents of Nauclea diderrichii. Part VII. Synthesis of nauclederine, naucleonine, and naucleonidine; spectroscopic evidence for the structures of $3 \alpha$-dihydrocadambine and two other constituents. Can. J. Chem. 1976, 54, 1262-1277.

14. Heitzman, M.E.; Neto, C.C.; Winiarz, E.; Vaisberg, A.J.; Hammond, G.B. Ethnobotany, phytochemistry and pharmacology of Uncaria (Rubiaceae). Phytochemistry 2005, 66, 5-29.

15. Takayama, H.; Kitajama, M.; Kogure, N. Chemistry of indole alkaloids related to the corynanthetype from Uncaria, Nauclea and Mitragyna Plants. Curr. Org. Chem. 2005, 9, 1445-1464.

16. Gonzalez, A.G.; Guilermo, J.A.; Ravelo, A.G.; Jimenez, I.A. 4, 5-Dihydroblumenol A, a new norisoprenoid from Perrotetia multiflora. J. Nat. Prod. 1994, 57, 400-402.

17. Jingyong, S.; Hongxiang, L.; Shengjun, D.; Hui, X.; Feng, Z.; Ke, L. Indole alkoloids from Nauclea officinalis with weak antimalarial activity. Phytochemistry 2008, 69, 1405-1410. 
18. Lavilla, R.; Gullón, F.; Bosch, J. Regioselective syntheses of the indolopyridine alkaloid nauclefine, angustine, dihydroangustine and naucletine from a common intermediate. $J$. Chem. Soc. Chem. Commun. 1995, 16, 1675-1676.

19. Morita, H.; Iizuka, T.; Choo, C.Y.; Chan, K.L.; Takeya, K.; Kobayashi, J. Cyclonatsudamine A, a new vasodilator cyclic peptide from Citrus natsudaidai. Bioorg. Med. Chem. Lett. 2006, 16, 4609-4611.

20. Mukhtar, M.R.; Nafiah, M.A.; Awang, K.; Thomas, N.F.; Zaima, K.; Morita, H.; Litaudon, M.; Hadi, A.H.A. $\alpha^{\prime}$-Oxoperakensimines A-C, new bisbenzylisoquinoline alkaloids from Alseodaphne perakensis (Gamble) Kosterm. Heterocycles 2009, 78, 2085-2092.

21. Mukhtar, M.R.; Zahari, A.; Nafiah, M.A.; Hadi, A.H.A.; Thomas, N.F.; Arai, H.; Morita, H.; Liataudon, M.; Awang, K. 3',4'-Dihydronorstephasubine, a new bisbenzylisoquinoline from the bark of Alseodaphne corneri. Heterocycles 2009, 78, 2571-2578.

22. Syazreen, N.S.; Mukhtar, M.R.; Hadi, A.H.A.; Awang, K.; Hazni, H.; Zahari, A.; Litaudon, M.; Zaima, K.; Morita, H. Lancifoliaine, a new bisbenzylisoquinoline from the bark of Litsea lancifolia. Molecules 2011, 16, 3119-3127.

Sample Availability: Not available.

(C) 2012 by the authors; licensee MDPI, Basel, Switzerland. This article is an open access article distributed under the terms and conditions of the Creative Commons Attribution license (http://creativecommons.org/licenses/by/3.0/). 